\title{
Analysis of antibiotic usage for viral community-acquired pneumonia in adults
}

\author{
Rongmeng Jiang ${ }^{1}$, Bing $\operatorname{Han}^{1}$, Chang Dou ${ }^{2}$, Fei Zhou ${ }^{3}$, Bin Cao $(\bowtie)^{3}$, Xingwang Li $(\bowtie)^{1}$ \\ ${ }^{1}$ Department of Infectious Diseases, Beijing Ditan Hospital, Beijing 100015, China; ${ }^{2}$ Department of Internal Medicine, Beijing Capital \\ International Airport Hospital, Beijing 100621, China; ${ }^{3}$ Department of Respiratory and Critical Care Medicine, China-Japan Friendship \\ Hospital, Beijing 100029, China
}

(C) Higher Education Press 2020

\begin{abstract}
The rationale for the antibiotic treatment of viral community-acquired pneumonia (CAP) in adults was analyzed to develop a clinical reference standard for this condition. Clinical data from 166 patients diagnosed with viral pneumonia across 14 hospitals in Beijing from November 2010 to December 2017 were collected. The indications for medications were evaluated, and the rationale for the use of antibiotics was analyzed. A total of 163 $\mathbf{( 9 8 . 3 \% )}$ patients with viral pneumonia were treated with antibiotics. A combination of C-reactive protein (CRP) and procalcitonin (PCT) was used as markers to analyze the possible indications for antibiotic use. With threshold levels set at $0.25 \mu \mathrm{g} / \mathrm{L}$ for $\mathrm{PCT}$ and $20 \mathrm{mg} / \mathrm{L}$ for CRP, the rate of unreasonable use of antibiotics was $55.2 \%$. By contrast, at a CRP level threshold of $60 \mathrm{mg} / \mathrm{L}$, the rate of antibiotic misuse was $77.3 \%$. A total of 39 of the 163 (23.9\%) patients did not meet the guidelines for drug selection for viral CAP in adults. The unreasonable use of antibacterial drugs for the treatment of viral CAP in adults is a serious concern. Clinicians must reduce the unnecessary use of antibiotics.
\end{abstract}

Keywords adult; antibiotic; viral pneumonia

\section{Introduction}

Community-acquired pneumonia (CAP) is a common infectious disease with a significant mortality rate. Although various microbial infections are associated with this disease, the importance of viruses has received substantial attention. A virus is detected in $15 \%$ to $34.9 \%$ of patients with adult CAP and normal immune function [1-4]. Viral pneumonia accounts for $23 \%$ of all cases of adult CAP [5]. The influenza virus is the causative agent in $38.2 \%$ of patients diagnosed with viral pneumonia. Other common viruses include the parainfluenza virus (16.0\%), the rhinovirus $(15.6 \%)$, the adenovirus $(15.3 \%)$, the human metapneumovirus $(5.3 \%)$, and respiratory syncytial virus and enterovirus (less than 5\%) [3]. Almost all patients with CAP, including viral pneumonia, are treated with antibiotics probably due to the diagnostic difficulties involving most viral infections, the lack of clinical insight into viral

Received July 11, 2019; accepted November 2, 2019

Correspondence: Xingwang Li, ditanlxw@163.com;

Bin Cao, caobin_ben@163.com pneumonia, and inadequate knowledge of the indications for the use of antimicrobial agents in CAP. However, standard guidelines do not specify whether antibiotics should be used for the treatment of viral pneumonia. Therefore, the use of antibiotics in this condition may be unwarranted.

This study aimed to analyze the rationale for the use of antibiotics in 166 patients diagnosed with viral pneumonia and provide a clinical reference standard for its treatment.

\section{Methods}

Case source

Clinical data from 166 patients diagnosed with viral pneumonia across 14 hospitals in Beijing from November 2010 through December 2017 were collected.

\section{Inclusion/exclusion criteria}

The inclusion criteria were as follows: (1) patients $\geqslant 14$ years of age and meeting the diagnostic criteria for 
pneumonia stipulated by the "Guidelines for the Diagnosis and Treatment of Community-Acquired Pneumonia in Adults in China" [6]; (2) patients with clinical features of viral pneumonia, including fever with respiratory symptoms and with or without dyspnea (respiratory rate $>30 / \mathrm{min}$ ); normal or low white blood cell count with or without thrombocytopenia; and unilateral or bilateral chest CT findings of multiple or diffuse, patchy, or ground glass infiltrates (with or without consolidation) [7]; and (3) patients with a positive virus test.

The exclusion criteria were as follows: (1) patients with clear evidence of bacterial infection and atypical pathogen infection, such as Streptococcus pneumoniae, Legionella pneumophila, Mycoplasma pneumoniae, and Chlamydia; (2) patients with procalcitonin (PCT) level $\geqslant 0.5 \mu \mathrm{g} / \mathrm{L}$; (3) patients with known or suspected active tuberculosis; (4) patients with HIV infection, agranulocytosis, or organ transplantation and patients undergoing chemotherapy; or (5) patients meeting the diagnostic criteria for severe pneumonia (CURB-65 $\geqslant 3$ ) stated in the "Guidelines for the Diagnosis and Treatment of Community-Acquired Pneumonia in Adults in China" [6].

\section{Outcome measurements}

The baseline characteristics, including patient's age and gender, were collected. Clinical information, laboratory tests, and imaging results were documented. The treatment with specific antibiotics was also recorded. The rate of unreasonable antibiotic use was calculated by dividing the number of patients who actually received antibiotics by the number of patients who were indicated for antibiotic intervention.

Parameters that warranted the use of antibiotics were (1) $0.25 \mu \mathrm{g} / \mathrm{L} \leqslant$ PCT $<0.5 \mu \mathrm{g} / \mathrm{L}$ regardless of CRP results; and (2) $\mathrm{PCT}<0.25 \mu \mathrm{g} / \mathrm{L}$ (or no result) but $\mathrm{CRP} \geqslant 20 \mathrm{mg} / \mathrm{L}$ (or $60 \mathrm{mg} / \mathrm{L}$ ) [7].

\section{Results}

A total of 166 patients, including 90 (54.2\%) males and 76 $(45.8 \%)$ females, with viral pneumonia met the inclusion criteria. The patients' age ranged from 14 years to 97 years, with a median age of $52.0(33.8-71.0)$ years. Thus, the study included 53 (31.9\%) young (14-40 years), 62 (37.4\%) middle-aged (41-64 years), and 51 (30.7\%) elderly $(\geqslant 65$ years) patients.

All of the cases included were noncritical and had no evidence of pathogenic infection caused by bacteria, Mycoplasma, or other pathogens. The viruses detected in the current study are listed in Table 1 . The majority of the patients $(92.8 \%)$ were infected with at least one type of virus, and the influenza virus was the most common virus detected. Each patient's condition was assessed using the
CURB-65 score. All patients belonged to either low- (164 cases) or intermediate-risk ( 2 cases) categories. Antibacterial drugs were used in 163 out of 166 patients (98.2\%). If no difference was found in the clinical outcomes between patients who use and those who do not use antibiotics, the irrational use of antimicrobials may be proven. However, given that only three patients in this study did not use antibiotics, comparing the effects of antibiotics on prognosis was statistically impossible.

Only $64(39.3 \%)$ of the 163 patients who were treated with antibiotics underwent the PCT test. Among these patients, $55(33.8 \%)$ had a PCT $<0.25 \mu \mathrm{g} / \mathrm{L}$ and $9(5.5 \%)$ had a PCT $\geqslant 0.25 \mu \mathrm{g} / \mathrm{L}$ but $<0.5 \mu \mathrm{g} / \mathrm{L}$. Among all of the patients, $132(81.0 \%)$ were tested for C-reactive protein (CRP); 64 (39.3\%) cases showed $<20 \mathrm{mg} / \mathrm{L}$ CRP, 36 $(22.1 \%)$ cases showed $\geqslant 20 \mathrm{mg} / \mathrm{L}$ but $<60 \mathrm{mg} / \mathrm{L}$ CRP, and $32(19.6 \%)$ cases showed $\geqslant 60 \mathrm{mg} / \mathrm{L}$ CRP. At threshold values of $0.25 \mu \mathrm{g} / \mathrm{L}$ for PCT and $20 \mathrm{mg} / \mathrm{L}$ for CRP, the rate of unreasonable use of antibiotics was $55.2 \%$, whereas at threshold value of $60 \mathrm{mg} / \mathrm{L}$ for CRP, the rate of unreasonable use of antibiotics was $77.3 \%$ (Table 2).

A total of $114(70.0 \%)$ patients were exposed to only a single type of antibiotic, and $69(42.3 \%)$ were administered with quinolones. Four patients did not meet the guidelines for the specific antibiotic used (Table 3).

A total of $48(29.4 \%)$ and $1(0.6 \%)$ patients were treated with two and three antibiotics, respectively. Quinolonebased drugs were used to treat $33(20.2 \%)$ patients, 21 (12.9\%) of which were exposed to combined treatment with $\beta$-lactam/enzyme inhibitors. Thirty-five patients did not meet the guidelines for the specific antibiotic used (Table 4).

\section{Discussion}

In addition to the clinical manifestations and the pulmonary X-ray findings, the diagnosis of viral pneumonia relies on the detection or culture of viral nucleic acids or viral antigens in the upper (e.g., nasopharyngeal aspirates) and the lower (e.g., sputum) respiratory specimens. The virus is isolated, or the double serum IgG is increased by four times or more. At least 26 viruses are associated with viral CAP.

Viral pneumonia, which often occurs in children under the age of five years or in individuals older than 65 years, usually occurs as seasonal outbreaks [8]. Almost 50\% of CAP cases among young children are attributed to viruses $[9,10]$. The incidence of viral pneumonia in adults has been underestimated but is quite common. The incidence of CAP in adults due to a viral etiology is $23 \%$ [5]. In our study, viral pneumonia in adults occurred in all age groups, and the proportions of young and middle-aged patients were higher than that of elderly patients.

Simple viral pneumonia does not require antibiotic 
Table 1 Viruses detected in the study

\begin{tabular}{|c|c|c|c|c|c|}
\hline Number of viruses & Number of patients & Percentage & Viruses & Number of patients & Percentage \\
\hline \multirow[t]{7}{*}{1} & 154 & $92.8 \%$ & Influenza virus & 87 & $52.4 \%$ \\
\hline & & & Adenovirus & 22 & $13.3 \%$ \\
\hline & & & Rhinovirus & 16 & $9.6 \%$ \\
\hline & & & Parainfluenza virus & 10 & $6.0 \%$ \\
\hline & & & Human metapneumovirus & 9 & $5.4 \%$ \\
\hline & & & Respiratory syncytial virus & 9 & $5.4 \%$ \\
\hline & & & Human coronavirus & 1 & $0.6 \%$ \\
\hline \multirow[t]{4}{*}{2} & 9 & $5.4 \%$ & Influenza virus + parainfluenza virus & 4 & $2.4 \%$ \\
\hline & & & Influenza virus + human coronavirus & 2 & $1.2 \%$ \\
\hline & & & Influenza virus + adenovirus & 2 & $1.2 \%$ \\
\hline & & & $\begin{array}{l}\text { Parainfluenza virus }+ \text { human } \\
\text { metapneumovirus }\end{array}$ & 1 & $0.6 \%$ \\
\hline \multirow[t]{2}{*}{3} & 3 & $1.8 \%$ & $\begin{array}{l}\text { Rhinovirus }+ \text { respiratory syncytial virus } \\
+ \text { adenovirus }\end{array}$ & 2 & $1.2 \%$ \\
\hline & & & $\begin{array}{l}\text { Influenza virus }+ \text { adenovirus } \\
+ \text { parainfluenza virus }\end{array}$ & 1 & $0.6 \%$ \\
\hline Total & 166 & $100.0 \%$ & & 166 & $100.0 \%$ \\
\hline
\end{tabular}

Table 2 Inflammatory index

\begin{tabular}{lllll}
\hline Index & PCT $<0.25$ & $0.25 \leqslant$ PCT $<0.5$ & No PCT & Total \\
\hline CRP $<20$ & 22 & 5 & 37 & 64 \\
$20 \leqslant$ CRP $<60$ & 17 & 0 & 19 & 36 \\
CRP $\geqslant 60$ & 13 & 4 & 15 & 32 \\
No CRP & 3 & 0 & 28 & 31 \\
Total & 55 & 9 & 99 & 163 \\
\hline
\end{tabular}

The two following biochemical scenarios were defined as warranting the use of antibiotics: (1) $0.25 \mu \mathrm{g} / \mathrm{L} \leqslant \mathrm{PCT}<0.5 \mu \mathrm{g} / \mathrm{L}$ regardless of CRP results; (2) $\mathrm{PCT}<0.25 \mu \mathrm{g} / \mathrm{L}$ (or no result) but CRP $\geqslant 20 \mathrm{mg} / \mathrm{L}$ (or $60 \mathrm{mg} / \mathrm{L}$ ).

CRP, C-reactive protein; PCT, procalcitonin.

Table 3 Single-drug regimens

\begin{tabular}{lll}
\hline Drug category & $\begin{array}{l}\text { Patients with underlying } \\
\text { diseases or elderly } \\
\text { patients }\end{array}$ & $\begin{array}{c}\text { Young adults without } \\
\text { underlying diseases }\end{array}$ \\
\hline Quinolones & 29 & 40 \\
Cephamycin & 10 & 2 \\
Macrolides & 4 & 5 \\
Cephalosporins & 5 & 6 \\
$\begin{array}{l}\text { B-lactam/enzyme } \\
\text { inhibitors }\end{array}$ & 7 & 3 \\
Carbapenem & 3 & 0 \\
\hline
\end{tabular}

Macrolides are not recommended to be used alone in patients with underlying diseases or in elderly patients [6].

treatment. Hence, the features of CAP must be distinguished with a viral etiology, and sound clinical judgment must be exercised for the use of antibiotics in clinical practice. The clinical symptoms of bacterial and viral pneumonia are variable and overlapping. Although no well-defined clinical or imaging features are available to distinguish between these two entities, they can be differentiated using biomarkers. Increased CRP and PCT levels are highly suggestive of bacterial infection [11]. Varying levels of serum PCT can be used to distinguish bacterial pneumonia from viral pneumonia, with the highest sensitivity $(55 \%)$ at a threshold of $0.5 \mu \mathrm{g} / \mathrm{L}$. When the threshold of serum PCT is $\geqslant 0.5 \mu \mathrm{g} / \mathrm{L}$, the positive and negative predictive values for bacterial infection are $73.7 \%$ and $91.5 \%$, respectively [12]. However, using this threshold of PCT as a guideline for antibiotic use comes with a caveat. In China, a consensus among experts indicates that a local infection may occur at PCT $\geqslant 0.25 \mu \mathrm{g} / \mathrm{L}$ and $<0.5 \mu \mathrm{g} / \mathrm{L}$, warranting the use of antibiotics [13]. At PCT $<0.25 \mu \mathrm{g} / \mathrm{L}$, the use of antibiotics is not recommended. At PCT $>0.25 \mu \mathrm{g} / \mathrm{L}$, antibiotic use is encouraged, and at PCT $>0.5 \mu \mathrm{g} / \mathrm{L}$, antibiotic use is strongly recommended. The standards used to regulate the antibiotic treatment for CAP can reduce drug use and modulate the course of treatment without increasing patient morbidity $[14,15]$. When the CRP threshold is considered as $20 \mathrm{mg} / \mathrm{L}$, the sensitivity 
Table 4 Combination therapy

\begin{tabular}{lll}
\hline Drug category & $\begin{array}{l}\text { Patients with } \\
\text { underlying } \\
\text { diseases or } \\
\text { elderly patients }\end{array}$ & $\begin{array}{l}\text { Young adults } \\
\text { without } \\
\text { underlying } \\
\text { diseases }\end{array}$ \\
\hline $\begin{array}{l}\text { Macrolides + cephamycin } \\
\text { Macrolides + penicillin }\end{array}$ & 2 & 0 \\
$\begin{array}{l}\text { Macrolides + } \beta \text {-lactam/enzyme } \\
\text { inhibitors }\end{array}$ & 1 & 1 \\
$\begin{array}{l}\text { Macrolides + cephalosporins } \\
\text { Quinolones + } \beta \text {-lactam/enzyme }\end{array}$ & 1 & 4 \\
inhibitors & 2 & 5 \\
$\begin{array}{l}\text { Quinolones + cephamycin } \\
\text { Quinolones + cephalosporins }\end{array}$ & 2 & 19 \\
$\begin{array}{l}\text { Quinolones + aminoglycosides } \\
\begin{array}{l}\text {-lactam/enzyme inhibitors } \\
+ \text { cephamycin }\end{array}\end{array}$ & 0 & 3 \\
$\begin{array}{l}\text { Macrolides + cephalosporins } \\
+ \text { aminoglycosides }\end{array}$ & 1 & 6 \\
\hline
\end{tabular}

The three following cases did not meet the guidelines: (1) combination of drugs based on quinolones; (2) combination of $\beta$-lactam/enzyme inhibitors with cephalosporin; and (3) combination of three antibiotics.

and specificity for the detection of bacterial infection is $86 \%$ and 67\%, respectively [16]. Ruuskanen et al. suggested that patients with bacterial pneumonia frequently have acute disease onset, high fever, high white blood cell counts, $\mathrm{CRP}>60 \mathrm{mg} / \mathrm{L}, \mathrm{PCT}>0.5 \mu \mathrm{g} / \mathrm{L}$, and consolidations in the chest image study. Antibiotic treatments are recommended for these patients [7]. In the current study, all of the patients had no typical sign of bacterial pneumonia in the lung X-ray examination. All of them had at least one positive virus test result in respiratory specimens, and no positive result for bacteria and atypical pathogen, such as Mycoplasma, Chlamydia, Streptococcus, and Legionella. No exacerbation occurred in the later stage, and no patient died. As a retrospective study, only $132(81.0 \%)$ of the patients in this group had CRP results, and $64(39.3 \%)$ had PCT results. The rate of antibiotic use in 166 patients with viral pneumonia was $98.2 \%$, and no evidence of other pathogens, such as bacteria or Mycoplasma, was observed. When a combination of inflammatory biomarkers, such as PCT and CRP, was used to guide antibiotic treatment (namely, $0.25 \mu \mathrm{g} / \mathrm{L} \leqslant \mathrm{PCT}<0.5$ $\mu \mathrm{g} / \mathrm{L}$ or PCT $<0.25 \mu \mathrm{g} / \mathrm{L}$ (or no results) but CRP $\geqslant 20$ $\mathrm{mg} / \mathrm{L}($ or $60 \mathrm{mg} / \mathrm{L}$ )) as an indication for medication, the rate of unreasonable use of antibiotics was $55.2 \%$ under a CRP threshold of $20 \mathrm{mg} / \mathrm{L}$. However, at a CRP threshold set at $60 \mathrm{mg} / \mathrm{L}$, the rate of unreasonable use was $77.3 \%$. In terms of the specific antibiotic used, 39 (23.9\%) patients did not meet the guidelines for the specific antibiotics they were given. Given that the clinical symptoms of this group of patients meet the symptoms of viral pneumonia and have positive results of respiratory virus detection, in the absence of evidence of bacterial infection, these patients may have unreasonable use of antibacterial drugs. This finding suggests that antibiotics were not indicated for nearly a quarter of all patients, and the specific antibiotics given were not warranted.

Several factors contributed to the unreasonable use of antibacterial drugs for the treatment of viral pneumonia. Clinicians lack sufficient knowledge of viral pneumonia or the indications for antibiotic use in this condition. CAP guidelines do not mention the mode of antibiotic use in viral pneumonia. Furthermore, respiratory viruses other than the influenza virus are often difficult to detect or diagnose clearly. Hence, empirical anti-infective treatment leads to an increase in the unreasonable use of antibiotics. Although the diagnostic techniques for detection of influenza virus are relatively common, more than $97 \%$ of patients with influenza viral pneumonia are treated with antibacterial drugs in the absence of evidence of bacterial infection, which is clearly an unreasonable approach. Among the patients analyzed in this study, $99(60.7 \%)$ did not undergo the PCT test, which is a diagnostic and prognostic indicator and one of the parameters guiding the judicious use of antibiotics and differential diagnosis of bacterial and viral infections. The clinical ignorance of this indicator may be one of the reasons for the irrational use of drugs. Therefore, patients diagnosed with CAP must be evaluated for PCT, which facilitates the assessment of the clinical condition and plays a guiding role in differential diagnosis.

Our study has several limitations. Only a limited number of patients were recruited in the study mainly due to our strict inclusion and exclusion criteria (for example, positive viral test, age limitation, and immune status). Data related to comorbidities, which may influence the selection of antibiotics, were not included. Patients with severe pneumonia (CURB-65 $\geqslant 3$ ) were excluded because this group of patients frequently received antibiotics due to their critical clinical condition. Therefore, our study results cannot be generalized to patients with high-risk viral pneumonia. Antibiotic usage in patients were only reviewed, but the clinical outcomes or adverse events among patients treated with or without antibiotics were not investigated. These issues should be addressed in future studies.

The results of this study are intended to remind clinicians who make decisions on the usage of antibiotics with CAP to investigate for further clues, such as purulent cough, rust stains, elevated peripheral blood leukocytes and neutrophils, significantly elevated CRP (e.g., > 40 $\mathrm{mg} / \mathrm{L}$ ), and PCT of $>0.25 \mu \mathrm{g} / \mathrm{L}$. If no evidence of positive results of bacteriological test is obtained, results suggest no bacterial infection. Thus, further virologic tests should be implemented to aid in clinical decision-making. 


\section{Conclusions}

The unreasonable use of antibacterial drugs for the treatment of viral pneumonia is a serious concern. Clinicians should increase their knowledge base about this disease and strictly adhere to the indications for the rational use of antibacterial drugs in the management of viral pneumonia.

\section{Acknowledgements}

We thank the 14 hospitals for their support and collaboration with case information. We also thank the International Science Editing for editing this manuscript. This work was supported by the Key Medical Specialty Program of Sailing Plans organized by Beijing Municipal Administration of Hospitals (No. ZYLX201602); the study on new treatment methods for non-influenza virus pneumonia organized by Beijing Municipal Science and Technology Commission (No. D151100002115002); the National Science and Technology Major Project, subtopic 2; and the New Technology and Project on Intervention and Elimination of Cytokine Storm and Secondary Infection in Acute Severe Respiratory Infectious Diseases (No. 2017ZX10204401002).

\section{Compliance with ethics guidelines}

Rongmeng Jiang, Bing Han, Chang Dou, Fei Zhou, Bin Cao, and Xingwang Li declare that they have no conflict of interest. All procedures followed were in accordance with the ethical standards of the responsible committee on human experimentation (institutional and national) and with the Helsinki Declaration of 1975, as revised in 2000 (5). Informed consent was obtained from all patients for being included in the study.

\section{References}

1. Cao B, Ren LL, Zhao F, Gonzalez R, Song SF, Bai L, Yin YD, Zhang YY, Liu YM, Guo P, Zhang JZ, Wang JW, Wang C. Viral and Mycoplasma pneumoniae community-acquired pneumonia and novel clinical outcome evaluation in ambulatory adult patients in China. Eur J Clin Microbiol Infect Dis 2010; 29(11): 1443-1448

2. Liu Y, Chen M, Zhao T, Wang H, Wang R, Cai B, Cao B, Sun T, Hu Y, Xiu Q, Zhou X, Ding X, Yang L, Zhuo J, Tang Y, Zhang K, Liang D, Lv X, Li S, Liu Y, Yu Y, Wei Z, Ying K, Zhao F, Chen P, Hou $X$. Causative agent distribution and antibiotic therapy assessment among adult patients with community acquired pneumonia in Chinese urban population. BMC Infect Dis 2009; 9 (1): 31-39

3. Qu JX, Gu L, Pu ZH, Yu XM, Liu YM, Li R, Wang YM, Cao B, Wang C; Beijing Network for Adult Community-Acquired Pneumonia (BNACAP). Viral etiology of community-acquired pneumonia among adolescents and adults with mild or moderate severity and its relation to age and severity. BMC Infect Dis 2015; 15(1): 89-97
4. Zhan Y, Yang Z, Chen R, Wang Y, Guan W, Zhao S. Respiratory virus is a real pathogen in immunocompetent community-acquired pneumonia: comparing to influenza like illness and volunteer controls. BMC Pulm Med 2014; 14(1): 144-152

5. Jain S, Self WH, Wunderink RG, Fakhran S, Balk R, Bramley AM, Reed C, Grijalva CG, Anderson EJ, Courtney DM, Chappell JD, Qi C, Hart EM, Carroll F, Trabue C, Donnelly HK, Williams DJ, Zhu Y, Arnold SR, Ampofo K, Waterer GW, Levine M, Lindstrom S, Winchell JM, Katz JM, Erdman D, Schneider E, Hicks LA, McCullers JA, Pavia AT, Edwards KM, Finelli L; CDC EPIC Study Team. Community-acquired pneumonia requiring hospitalization among U.S. adults. N Engl J Med 2015; 373(5): 415-427

6. Qu JM, Cao B. Guidelines for the diagnosis and treatment of adult community acquired pneumonia in China (2016 Edition). Chin J Tuberc Respir Dis (Zhonghua Jie He He Hu Xi Za Zhi) 2016; 39(4): 241-242 (in Chinese)

7. Ruuskanen O, Lahti E, Jennings LC, Murdoch DR. Viral pneumonia. Lancet 2011; 377(9773): 1264-1275

8. Galván JM, Rajas $\mathrm{O}$, Aspa J. Review of non-bacterial infections in respiratory medicine: viral pneumonia. Arch Bronconeumol 2015; 51(11): 590-597

9. Harris M, Clark J, Coote N, Fletcher P, Harnden A, McKean M, Thomson A; British Thoracic Society Standards of Care Committee. British Thoracic Society guidelines for the management of community acquired pneumonia in children: update 2011. Thorax 2011; 66(Suppl 2): ii1-ii23

10. Don M, Canciani M, Korppi M. Community-acquired pneumonia in children: what's old? What's new? Acta Paediatr 2010; 99(11): 1602-1608

11. Bello S, Mincholé E, Fandos S, Lasierra AB, Ruiz MA, Simon AL, Panadero C, Lapresta C, Menendez R, Torres A. Inflammatory response in mixed viral-bacterial community-acquired pneumonia. BMC Pulm Med 2014; 14(1): 123-134

12. Wang MM, Liu TL, Cui SN, Sun YQ, Zhang J. Comparison of serum procalcitonin levels in children with viral infection and bacterial infection. Chin J Contemp Pediatr (Zhongguo Dang Dai Er Ke Za Zhi ) 2004; 6(5): 432-434 (in Chinese)

13. Chinese College of Emergency Physicans (CCEP). Expert consensus on clinical practice of severe pneumonia in the emergency department in China. Chin J Crit Care Med (Zhongguo Ji Jiu Yi Xue) 2016; 36(2): 97-107 (in Chinese)

14. Christ-Crain M, Stolz D, Bingisser R, Müller C, Miedinger D, Huber PR, Zimmerli W, Harbarth S, Tamm M, Müller B. Procalcitonin guidance of antibiotic therapy in community-acquired pneumonia: a randomized trial. Am J Respir Crit Care Med 2006; 174(1): 84-93

15. Long W, Deng X, Zhang Y, Lu G, Xie J, Tang J. Procalcitonin guidance for reduction of antibiotic use in low-risk outpatients with community-acquired pneumonia. Respirology 2011; 16(5): 819824

16. Lubell Y, Blacksell SD, Dunachie S, Tanganuchitcharnchai A, Althaus T, Watthanaworawit W, Paris DH, Mayxay M, Peto TJ, Dondorp AM, White NJ, Day NP, Nosten F, Newton PN, Turner P. Performance of C-reactive protein and procalcitonin to distinguish viral from bacterial and malarial causes of fever in Southeast Asia. BMC Infect Dis 2015; 15(1): 511-520 